\title{
FACTORS INFLUENCING STUDENTS' CHOICE OF FAST FOOD RESTAURANTS
}

\author{
Ivana Blešič ${ }^{1}$, Jovanka Popov Raljič́2, Tatjana Pivac ${ }^{3}$, Milan Ivkov $^{4}$
}

\begin{abstract}
Summary
The global expansion of fast food consumption habits and the consequent change in the competitive environment led to greater market research and the targeting of consumer groups. On the other hand, the growth of the market and the increase in the number of fast food restaurants have encouraged consumers to pay more attention to the products they consume, that is, have influenced their interest in the diversity of factors that are decisive when choosing a restaurant.

This study investigates factors influencing students' choice of fast food restaurants. The study was conducted at University of Novi Sad. The results show that the most important influences on this choice are Food Quality, Nearness and Accessibility and Hygienic factors, primarily cleanliness of the restaurant, kitchen, and service personnel. Differences in fast food choice factors were found regarding the gender of respondents.
\end{abstract}

Key words: fast food restaurants, consumer behavior, students

JEL: $P 46$

\section{Introduction}

Food consumption away from home is an increasing phenomenon among all subcategories of the population across the world (Issahaku et al., 2014; Ares et al., 2009).

1 Ivana Blešić, Ph.D., Associate Professor, University of Novi Sad, Faculty of Sciences Department of Geography, Tourism and Hotel Management, Trg Dositeja Obradovica 3, 21 000 Novi Sad, Serbia, Phone: +381 2148 52835, E-mail: ivana.blesic@gmail.com

2 Jovanka Popov-Raljić, Ph.D., Full Professor, University of Novi Sad, Faculty of Sciences Department of Geography, Tourism and Hotel Management, Trg Dositeja Obradovica 3, 21 000 Novi Sad, Serbia, Phone: +381 2148 52835, E-mail: jovankaraljicpopov@gmail.com

3 Tatjana Pivac, Ph.D., Associate Professor, University of Novi Sad, Faculty of Sciences Department of Geography, Tourism and Hotel Management, Trg Dositeja Obradovica 3, 21 000 Novi Sad, Serbia, Phone: +381 2148 52835, E-mail:tatjana.pivac@dgt.uns.ac.rs

4 Milan Ivkov, Ph.D., Assistant Professor, University of Novi Sad, Faculty of Sciences Department of Geography, Tourism and Hotel Management, Trg Dositeja Obradovica 3, 21 000 Novi Sad, Serbia, Phone:+381 2148 52842, E-mail:milan.ivkov@gmail.com

EP 2018 (65) 1 (257-268) 
Definitions of fast food in the scientific literature are different. Some authors define it as packed, quickly prepared and suitable meals, while others take a narrower definition of fast food and define it as the food purchased in one of the biggest fast food chains such as McDonald's (Kirsten, 2008). Fast food is characterized by low prices, large portions and energy value of food that is rich in calories and fats (Bowman, Vinyard, 2004; Guthrie et al. 2002; Brindal et al. 2008; Olise et al., 2015). On average, a traditional fast food meal accounted for $47.47 \%$ of an $8400 \mathrm{~kJ}$ daily guideline (Brindal et al., 2008).

Modernization and fast pace of life shorten the time needed to prepare food, which affects the trend of eating meals in restaurants. This is not a passing trend but a daily need of a modern human. For this reason, food preparation in hospitality facilities must meet certain quality standards. Although food quality is often a primary determinant factor for a restaurant, other very important factors are service staff, price, menu, ambience and convenience.

Studying consumer behavior explores how individuals make decisions to spend their available resources (money, time, effort) to consume specific products. It includes research on what, why, how, when, where and how often consumers buy products (Kesić, 2006). The American Marketing Association (AMA) defines consumer behavior as "a dynamic interaction between thinking, behavior and events in the environment, based on which human beings manage aspects of the exchange in their lives" (Peter, Olson, 2008). The basic assumption of successful marketing is understanding consumer behavior in order to create a supply (marketing mix), that is, an adequate way of meeting the needs and wishes of consumers (Živković, 2011). Market research and the definition of targeted segments of consumers are crucial to the development of the appropriate marketing strategy of the restaurant.

\section{Literature review}

A review of previous research reveals a number of studies that defined market segments in the food service sector. For instance, Koo, Tao and Yeung (1999) used dining occasion or purpose as the preexisting criteria for segmentation. Results of the study indicate that customers who dine out due to different reasons (as families, for business, or as tourists) have different criteria in choosing a restaurant. Consumers who were in the group "family guests" gave a greater importance to the price compared to "business guests". Depending on the type of cuisine, Western food is more acceptable to business guests compared to those who came to the restaurant with their family. Oyewole (1999) used the frequency of consumer visits as a criterion for examining the determining factors for the choice of restaurants by consumers. The research results have shown that the importance of the ten distinguished attributes of the restaurant quality is different for visitors depending on their frequency of visits (less frequent, frequent and more frequent). Less frequent visitors attach greater importance to health aspects of food and child-friendly dimensions; frequent visitors are more concerned with communications and hygiene, while for more frequent visitors the most important are availability and expeditiousness. 
Many studies exploring the reasons why people consume fast food have pointed to convenience. The IGA survey reported that consumers generally consume fast food because of convenient locations and time constraints (FOODweek, 2008). Bryant and Dundes (2008) have examined student attitudes in the USA and Spain and have come to the conclusion that the most important factors in choosing fast food restaurants are the taste and smell of food. Convenience, cost, and menu choices are also distinguished as important factors for consuming food in fast-food restaurants (Driskell et al., 2006). In addition to the apparent advantages of fast foods related to quick and easy preparation, availability and relatively low cost, some researchers emphasize the hedonistic aspect of its consumption (Park, 2004). Clark and Wood (1998) comment that food quality and value appear to be the most significant restaurant attributes. Lewis (1981) also highlights the quality of food as the most important attribute for the selection of fast food restaurants. Prescott et al. (2002) and Steptoe et al. (1995) show that crucial factors include familiarity, price and taste. Similarly to the studies, the results of a survey conducted on a sample of 50.000 students at seven Australian universities showed that the greatest determinants of food-purchasing behavior were taste, followed by value for money, convenience, then cost (Tam et al., 2017). Some studies put emphasis on service staff in restaurants. Thus Becker et al. (1999) showed in their research that students from the USA have different expectations when it comes to restaurant services, as opposed to Hong Kong students. Students at the University of Hong Kong primarily appreciate respect, unobtrusive courtesy and personal hygiene of employees, while students from U.S.A. prefer eye contact, employee knowledge and personalized service.

Although the presented studies highlight the importance of individual factors for selecting restaurants by consumers, consumer behavior is a complex category that can not be fully defined by distinguishing individual attributes. In real world situations, the choice of restaurants is influenced by time pressures, specific environments, personal preferences, and social variables (Brindal, 2010).

\section{Methodology and description of the research}

The survey was conducted using random sample method through electronic means and social networks in the period from October to December 2016. The target group were students of all studing levels (basic, master and doctoral studies) at the University of Novi Sad. A sample of 279 respondents was obtained.

The self-administered questionnaire used in the study contained 33 attributes that were collected through a review of relevant literature (Aksoydan, 2007; Islam, Ulah, 2010; Koo et al., 1999). The first part of the questionnaire contained questions related to the characteristics of the respondents (gender, level of studies and Faculty), while the second part of the questionnaire focuses on the attributes of fast food restaurants. Questionnaire items were ranged on a 5-point Likert scale from 1 (not important) to 5 (very important).

All statistical analyzes were conducted using SPSS software (Statistical Package for Social Sciences, version 23.0). Data was analyzed using frequency distributions, percentages, means, T-test and factor analysis. 


\section{Results}

Characteristics of respondents. The sample included 154 (55.2\%) males and 125 (44.8\%) females among the respondents. In regards to the level of studies, more than half of the respondents are at basic/primary level of studies, while the smallest share of students is at doctoral level. The research involved students from six faculties of the University of Novi Sad (Table 1.). Their share in the sample ranges from $13.6 \%$ (Faculty of Philosophy) to $21.1 \%$ (Faculty of Medicine).

Table 1. Characteristics of respondents $(\mathrm{N}=279)$

\begin{tabular}{|l|r|r|}
\hline \multicolumn{1}{|c|}{ Variables } & \multicolumn{1}{c|}{$\begin{array}{c}\text { Sample } \\
\text { size }\end{array}$} & \multicolumn{1}{c|}{ Percentage } \\
\hline Level of study & 158 & 56.6 \\
\hline Higher education & 101 & 36.2 \\
\hline Master's degree & 20 & 7.2 \\
\hline Doctor's degree & & 55.2 \\
\hline Gender & 154 & 44.8 \\
\hline Male & 125 & 15.1 \\
\hline Female & & 18.3 \\
\hline Faculty & 42 & 17.2 \\
\hline Faculty of Sciences & 51 & 14.7 \\
\hline Faculty of Agriculture & 48 & 13.6 \\
\hline Faculty of Tehnology & 41 & 21.1 \\
\hline Faculty of Technical Sciences & 38 & 59 \\
\hline Faculty of Philosophy & & \\
\hline Faculty of Medicine & & \\
\hline
\end{tabular}

Factor analysis. Factor analysis (principal component analysis) was conducted to determine the basic dimensions of 33 attributes of fast food restaurants. In this study, all factors with eigenvalue greater than 1 and with factor loadings more than 0.3 were retained. The results of the factor analysis, which suggested a five - factor solution, included 33 hotel attributes and explained $77.69 \%$ of the variance. The Kaiser - Meyer - Olkin (KMO) overall measure of sampling adequacy was 0.76 which was middling (Kaiser, 1974) and Bartlett's test of sphericity was significant $(p=0.000)$. The results of the factor analysis produced a clean factor structure with relatively higher loadings on the appropriate factors. The Cronbach's $\alpha$ values for each factor were greater than 0.7 (Nunnally, 1978). The results showed that the Cronbach's $\alpha$ coefficients of the five factors ranged from 0.78 to 0.97 . Table 2 shows the results of the factor analysis.

Table 2. Results of factor analysis

\begin{tabular}{|c|c|r|r|r|r|}
\hline $\begin{array}{c}\text { Extraced } \\
\text { factors }\end{array}$ & Items & $\begin{array}{c}\text { Factor } \\
\text { loading }\end{array}$ & Eigenvalue & $\begin{array}{c}\text { Variance } \\
\text { explained }\end{array}$ & Cronbach's $\boldsymbol{\alpha}$ \\
\hline F1 - Hygiene & Cleanliness of restaurant & 0.855 & 9.934 & 28.57 & 0.96 \\
\hline
\end{tabular}




\begin{tabular}{|c|c|c|c|c|c|}
\hline $\begin{array}{l}\text { Extraced } \\
\text { factors }\end{array}$ & Items & $\begin{array}{l}\text { Factor } \\
\text { loading }\end{array}$ & Eigenvalue & $\begin{array}{l}\text { Variance } \\
\text { explained }\end{array}$ & Cronbach's $\alpha$ \\
\hline & $\begin{array}{l}\text { Cleanliness of service } \\
\text { personnel }\end{array}$ & 0.844 & & & \\
\hline & $\begin{array}{l}\text { Nail cleanliness of service } \\
\text { personnel }\end{array}$ & 0.869 & & & \\
\hline & $\begin{array}{l}\text { Service personnel's attention } \\
\text { to hygiene }\end{array}$ & 0.866 & & & \\
\hline & $\begin{array}{l}\text { Convenience of service } \\
\text { material }\end{array}$ & 0.846 & & & \\
\hline & $\begin{array}{l}\text { Cleanliness of china and } \\
\text { cutlery }\end{array}$ & 0.827 & & & \\
\hline & Cleanliness of food & 0.862 & & & \\
\hline & Cleanliness of kitchen & 0.860 & & & \\
\hline & Tidiness of kitchen & 0.897 & & & \\
\hline & $\begin{array}{l}\text { Cleanliness of kitchen } \\
\text { equipment }\end{array}$ & 0.746 & & & \\
\hline & $\begin{array}{l}\text { Cleanliness of kitchen staff } \\
\text { clothing }\end{array}$ & 0.795 & & & \\
\hline & $\begin{array}{l}\text { Kitchen staff's attention to } \\
\text { hygiene }\end{array}$ & 0.859 & & & \\
\hline & Cleanliness of toilet & 0.865 & & & \\
\hline \multirow[t]{7}{*}{ F2 - Service } & Clear and readable menu & 0.921 & 8.166 & 25.14 & 0.97 \\
\hline & $\begin{array}{l}\text { Good communication of } \\
\text { service personnel }\end{array}$ & 0.915 & & & \\
\hline & $\begin{array}{l}\text { Friendliness of service } \\
\text { personnel }\end{array}$ & 0.862 & & & \\
\hline & $\begin{array}{l}\text { Clear speech of service } \\
\text { personnel }\end{array}$ & 0.913 & & & \\
\hline & $\begin{array}{l}\text { Good behavior of service } \\
\text { personnel }\end{array}$ & 0.886 & & & \\
\hline & $\begin{array}{l}\text { Service knowledge of service } \\
\text { personnel }\end{array}$ & 0.878 & & & \\
\hline & Kitchen open to visitors & 0.917 & & & \\
\hline
\end{tabular}




\begin{tabular}{|c|c|c|c|c|c|}
\hline $\begin{array}{l}\text { Extraced } \\
\text { factors }\end{array}$ & Items & $\begin{array}{l}\text { Factor } \\
\text { loading }\end{array}$ & Eigenvalue & $\begin{array}{l}\text { Variance } \\
\text { explained }\end{array}$ & Cronbach's $\alpha$ \\
\hline & $\begin{array}{l}\text { Ease of making complaints } \\
\text { to manager }\end{array}$ & 0.933 & & & \\
\hline & $\begin{array}{l}\text { Prompt handling of } \\
\text { complaints }\end{array}$ & 0.923 & & & \\
\hline & Speed of service & 0.917 & & & \\
\hline \multirow[t]{3}{*}{$\begin{array}{l}\text { F3 - } \\
\text { Atmosphere }\end{array}$} & $\begin{array}{l}\text { General appearance of } \\
\text { restaurant }\end{array}$ & 0.969 & 3.067 & 9.84 & 0.94 \\
\hline & $\begin{array}{l}\text { Interior decoration of } \\
\text { restaurant }\end{array}$ & 0.936 & & & \\
\hline & Comfortable atmosphere & 0.913 & & & \\
\hline \multirow{4}{*}{$\begin{array}{l}\text { F4 - Nearness } \\
\text { and } \\
\text { Accessibility }\end{array}$} & Nearness of University & 0.823 & 2.636 & 8.33 & 0.85 \\
\hline & Accessibility & 0.893 & & & \\
\hline & Parking space & 0.644 & & & \\
\hline & Location of restaurant & 0.730 & & & \\
\hline \multirow[t]{3}{*}{$\begin{array}{l}\text { F5 - Food } \\
\text { Quality }\end{array}$} & Odour and taste of food & 0.328 & 1.834 & 5.80 & 0.78 \\
\hline & $\begin{array}{l}\text { Appearance/presentation of } \\
\text { food }\end{array}$ & 0.950 & & & \\
\hline & Menu-item variety & 0.888 & & & \\
\hline
\end{tabular}

The first factor labeled "Hygiene" explained $28.57 \%$ of the total variance with a reliability coefficient of 0.96 . This factor includes 14 items/questions related to hygienic safety in the process of food preparation. The second factor was "Service" explaining $25.14 \%$ of the total variance with a reliability coefficient of 0.97 . The second factor includes 10 items related to the quality of the service process and the staff. The third factor was labeled "Atmosphere" and explained 9.84\% of the variance with a reliability coefficient of 0.94 . The "Atmosphere" factor contains three items that reflect the appearance and ambience of the restaurant. The fourth factor, labeled "Nearness and Accessibility", accounted for $8.33 \%$ of the variance with a reliability coefficient of 0.85 . It contains four items related to the nearness, location and accessibility of the restaurant. The fifth factor was "Food quality" explaining $5.80 \%$ of the total variance with a reliability coefficient of 0.78 . The fifth factor contains three items related to the basic elements of food quality and supply of restaurant. 
Descriptive statistics. The results of the descriptive statistics shown in Table 3 indicate that for the surveyed students the most important factors are "Food quality", "Nearness and Accessibility" and "Hygiene". A small difference between the arithmetic means of their ratings indicates that the three factors mentioned above are of great importance for respondents when choosing a fast food restaurant. Factors "Service" and "Atmosphere" have less significance for respondents when it comes to choosing fast food restaurants. These results are logical because consumers do not stay too long in this type of restaurant, they often order food "to go" and service staff, services, arrangement and atmosphere of the restaurant are not crucial to them.

Looking at items with the highest arithmetic mean, it can be concluded that these are two questions from the fifth factor related to quality of food and supply - Appearance/ presentation of food (4.7849), Menu-item variety (4.7849), question from the fourth factor Accessibility (4.7061) and three questions from the hygiene factor - Tidiness of kitchen (4.6667), Nail cleanliness of service personnel (4.6416) and Service personnel's attention to hygiene (4.6344). Questions with the lowest values of the arithmetic means of the ratings belong to the third factor - Interior decoration of restaurant (3.3226), Comfortable atmosphere (3.3405) and General appearance of restaurant (3.4301). Standard deviations did not exceed value 1 and ranged from 0.48965 (Speed of service) to 0.92264 (Comfortable atmosphere).

Table 3. Mean ratings of items and factors

\begin{tabular}{|l|r|r|}
\hline \multicolumn{1}{|c|}{ Factors and Items } & \multicolumn{1}{c|}{ Mean } & \multicolumn{1}{c|}{ Std. Deviation } \\
\hline F1 - Hygiene & $\mathbf{4 . 4 7 7}$ & $\mathbf{0 . 5 0 3 1}$ \\
\hline Cleanliness of restaurant & 4.272 & 0.541 \\
\hline Cleanliness of service personnel & 4.290 & 0.548 \\
\hline Nail cleanliness of service personnel & 4.642 & 0.624 \\
\hline Service personnel's attention to hygiene & 4.634 & 0.625 \\
\hline Convenience of service material & 4.272 & 0.598 \\
\hline Cleanliness of china and cutlery & 4.491 & 0.640 \\
\hline Cleanliness of food & 4.531 & 0.586 \\
\hline Cleanliness of kitchen & 4.531 & 0.5799 \\
\hline Tidiness of kitchen & 4.667 & 0.5562 \\
\hline Cleanliness of kitchen equipment & 4.387 & 0.5696 \\
\hline Cleanliness of kitchen staff clothing & 4.373 & 0.5666 \\
\hline Kitchen staff's attention to hygiene & 4.570 & 0.5765 \\
\hline Cleanliness of toilet & 4.538 & 0.6552 \\
\hline F2 - Service & $\mathbf{3 . 7 8 1}$ & $\mathbf{0 . 5 7 5 5}$ \\
\hline Clear and readable menu & 3.642 & 0.4952 \\
\hline Good communication of service personnel & 3.778 & 0.6631 \\
\hline Friendliness of service personnel & 3.713 & 0.6866 \\
\hline Clear speech of service personnel & 3.767 & 0.6566 \\
\hline
\end{tabular}




\begin{tabular}{|l|r|r|}
\hline \multicolumn{1}{|c|}{ Factors and Items } & \multicolumn{1}{c|}{ Mean } & \multicolumn{1}{c|}{ Std. Deviation } \\
\hline Good behavior of service personnel & 3.792 & 0.6289 \\
\hline Service knowledge of service personnel & 3.918 & 0.7421 \\
\hline Kitchen open to visitors & 3.953 & 0.7306 \\
\hline Ease of making complaints to manager & 3.928 & 0.7457 \\
\hline Prompt handling of complaints & 3.660 & 0.5041 \\
\hline Speed of service & 3.660 & 0.4897 \\
\hline F3 - Atmosphere & $\mathbf{3 . 3 6 4}$ & $\mathbf{0 . 8 1 2 5}$ \\
\hline General appearance of restaurant & 3.430 & 0.8362 \\
\hline Interior decoration of restaurant & 3.323 & 0.8113 \\
\hline Comfortable atmosphere & 3.341 & 0.9226 \\
\hline F4 - Nearness and Accessibility & $\mathbf{4 . 5 4 5}$ & $\mathbf{0 . 5 0 8 7}$ \\
\hline Nearness of University & 4.570 & 0.6244 \\
\hline Accessibility & 4.706 & 0.5812 \\
\hline Parking space & 4.491 & 0.6167 \\
\hline Location of restaurant & 4.412 & 0.6221 \\
\hline F5 - Food quality & $\mathbf{4 . 5 9 9}$ & $\mathbf{0 . 4 2 5 7}$ \\
\hline Odour and taste of food & 4.294 & 0.5225 \\
\hline Appearance/presentation of food & 4.785 & 0.4839 \\
\hline Menu-item variety & 4.717 & 0.5181 \\
\hline
\end{tabular}

T-test of independent samples. T-test of independent samples was applied with an aim to compare attitudes of two groups of respondents - male and female. Results shown in Table 4 indicate that there is a statically significant difference regarding the gender of the respondents when the first factor "Hygiene" $(p<0.01)$ is concerned. Female respondents give higher marks to hygiene attributes of fast food restaurants than males.

Table 4. Results of T-test analysis

\begin{tabular}{|l|r|r|c|}
\hline Factor & \multicolumn{2}{|c|}{ Means } & \\
\hline & $\begin{array}{c}\text { Male } \\
(\mathrm{n}=154)\end{array}$ & $\begin{array}{c}\text { Female } \\
(\mathrm{n}=125)\end{array}$ & t-value \\
\hline F1- Hygiene & 4.3726 & 4.6049 & $-3.934 *$ \\
\hline
\end{tabular}

${ }^{*} p<0.001$

\section{Conclusion}

This study aimed to develop an instrument exploring the factors that influence students' choice of fast food restaurants. The study was conducted using a questionnaire that was proven to be reliable and valid. The results reveal important and less important factors in the choice of a fast food restaurants among students from University of Novi Sad. The most important choice factors were identified as quality of food, appearance/ 
presentation of food, menu-item variety, cleanliness of the restaurant, kitchen, service personnel and and nearness and accessibility of the University as well, while the least important factors were atmosphere and service.

By far the most important criterion for food quality is to be safe for consumers' health, although users are not often sufficiently aware of it, but in the first place they put sensory and even nutritional properties of food. The hospitality activity is very complex and specific in terms of ensuring safe and healthy food, given the dynamics of the process of preparation and finalization of food products, contact with equipment and surfaces, as well as the participants themselves who manipulate food. Supplying consumers with food that does not contain microbiological, chemical or any other contaminants is the basic principle of the program of the production of safe food and the protection of the health of the population (Popov-Raljić, Blešić, 2016).

The research results have shown that there are statistically significant differences in the importance of individual attributes for students depending on their gender. Female students have given statistically significantly higher ratings to questions related to the hygiene and cleanliness of restaurants, kitchen, food, and service personnel. Although constraints related to the sample size and the sampling method in this study do not allow generalization of the results obtained, some other findings showed that women scored a higher mean in concern for safe food than men (Liu, Niyongira, 2017), that women paid more attention to food safety issues than men because they take more responsibility for buying and preparing food (Liu et al., 2014), and that female were having more knowledge and willingness to pay for safe food than men (Liu et al., 2013).

This study recommends that fast food producers or distributors in Novi Sad should focus more on the quality of food, nearness and accessibility of University and cleanliness of restaurant, kitchen and service personnel. By complying with these recommendations, fast food restaurants will become more competitive on the market and will be able to meet the needs and expectations of a large and significant market segment - student population.

\section{Literature}

1. Aksoydan, E. (2007): Hygiene factors influencing customers' choice of dining-out units: findings from a study of University academic staff, Journal of Food Safety, no. 27, pp. 300-316.

2. Ares, G., Gimenez, A., Gambaro, A. (2009): Consumer perceived healthiness and willingness to try functional milk desserts. Influence of ingredient, ingredient name and health claim, Food Quality \& Preference, vol. 20, no. 1, pp. 50-56.

3. Becker, C., Murrmann, K.S., Murrmann, F.K. and Cheung,W.G. (1999): A pan cultural study of restaurant service expectations in the United States and Hong Kong, Journal of Hospitality and Tourism Research, vol. 23, no. 3, pp. 235-256.

4. Bowman, S.A., Vinyard B.T. (2004): Fast Food Consumption of U.S. Adults: Impact on Energy and Nutrient Intakes and Overweight Status, Journal of the American 
College of Nutrition, vol. 23, no. 2, pp. 163-168.

5. Brindal, E. (2010): Exploring fast food consumption behaviours and social influence, PhD Thesis, Faculty of Health Sciences, University of Adelaide, North Terrace, Adelaide South Australia, NOBLE Research Group; CSIRO Human Nutrition, Adelaide, South Australia.

6. Brindal E., Mohr P., Wilson C., Wittert G. (2008): Obesity and the Effects of Choice at a Fast Food Restaurant, Obesity Research \& Clinical Practice, no. 2, pp. 111-117.

7. Bryant, R., Dundes, L. (2008): Fast food perceptions: a pilot study of college students in Spain and the United States, Appetite, vol. 51, no. 2, pp. 327-30.

8. Clark, M., Wood, C.R (1998): Consumer loyalty in the restaurant industry: $A$ preliminary exploration of the issues, International Journal of Contemporary Hospitality Management, vol. 10, no. 4, pp. 139-144.

9. Driskell, J.A., Meckna, B.R., Scales, N.E. (2006): Differences exist in the eating habits of university men and women at fast-food restaurants, Nutrition Research, no. 26, pp. 524-530.

10. FOODweek (2008): Fast food quiz gets mixed results, FOODweek, August 22, pp. 5-6.

11. Guthrie, J.F., Lin, B.H., Frazao, E. (2002): Role of Food Prepared Away from Home in the American Diet, 1977-78 versus 1994-96: Changes and Consequences, Journal of Nutrition Education and Behavior, no. 34, pp. 140-150.

12. Islam, N., Ulah, S. (2010): Factors affecting consumers'preferences on fast food items in Bangladesh, The Journal of Applied Business Research, vol. 26, no. 4, pp. 131-146.

13. Issahaku, A., Hiamey, S.E, Afenyo, E.A. (2014): Students' food safety concerns and choice of eating place in Ghana, Food Control, no. 43, pp. 135-141.

14. Peter, J.P., Olson, J. C. (2008): Consumer Behaviour and Marketing strategy, pp. 1-555, McGraw Hill International Edition, Boston, USA.

15. Živković, R. (2011): Ponašanje potrošača, Univerzitet Singidunum, Beograd, Srbija.

16. Kaiser, H.F. (1974): An index of factorial simplicity, Psychometrika, vol. 39, no. 1, pp. 31-36.

17. Kesić, T. (2006): Ponašanje potrošača, Adeco, Zagreb, Hrvatska.

18. Kirsten, D.P. (2008): Fast-Food Consumption: Application and Extension of the Theory of planned Behaviour to Incorporate Affective Responses and Implicit Associations, PhD Thesis, School of Psychology and Discipline of Medicine, University of Adelaide, North Terrace, Adelaide South Australia.

19. Koo, L.C., Tao, F.K.C., Yeung, J.H.C(1999): Preferential segmentation of restaurant attributes through conjoint analysis, International Journal of Contemporary Hospitality Management, vol. 11, no. 5, pp. 242-250. 
20. Lewis, C.R (1981): Restaurant advertising: Appeals and consumer intentions, Journal of Advertising Research, vol. 21, no. 5, pp. 69-74.

21. Liu, R., Pieniak. Z., Verbeke, W. (2013): Consumers' attitudes and behaviour towards safe food in China: A review, Food Control, vol. 33, no. 1, pp. 93-104.

22. Liu, R., Pieniak. Z., Verbeke,W. (2014): Food-related hazards in China: Consumers'

23. perceptions of risk and trust in information sources, Food Control, no. 46, pp. 291298.

24. Liu, A., Niyongira, R. (2017): Chinese consumers food purchasing behaviors and awareness of food safety, Food Control, no. 79, pp. 185-191.

25. Nunnally, J.C. (1978): Psychometric theory, McGraw-Hill, New York, USA.

26. Olise, M.C., Okoli, M.I., Ekeke, J.N. (2015): Factors influencing customers patronage of fast food restaurants, a study of selected customers of fast food in Anambra State, Nigeria, International Journal of Economics, Commerce and Management, vol. 3, no. 11, pp. 686-701.

27. Oyewole, P. (1999): Multi-attribute dimensions of service quality in the fast food restaurant industry, Journal of Restaurant and Foodservice Marketing, vol. 3, no. 3/4, pp. 65-91.

28. Park, C. (2004): Efficient or enjoyable? Consumer values of eating-out and fast food restaurant consumption in Korea, International Journal of Hospitality Management, vol. 23, no. 1, pp. 87-94.

29. Peter, J.P., Olson, J. C. (2008): Consumer Behaviour and Marketing strategy, McGraw Hill International Edition, Boston, USA.

30. Popov-Raljić, J., Blešić, I. (2016): Bezbednost hrane - primena HACCP sistema u ugostiteljstvu $i$ hotelijerstvu (ISBN 978-86-7031-259-3), Univerzitet u Novom Sadu, Prirodno-matematički fakultet, Departman za geografiju. turizam i hotelijerstvo, Novi Sad, Srbija.

31. Prescott, J., Young, O., O’Neill, L., Yau, N.J.N, Stevens, R. (2002): Motives for food choice: a comparison of consumers from Japan, Taiwan, Malaysia and New Zealand, Food Quality and Preference, vol. 13, no. 7-8, pp. 489-495.

32. Steptoe, A., Pollard, T.M., Wardle, J. (2002): Development of a measure of the motives underlying the selection of food: the food choice questionnaire, Appetite, vol. 25, no. 3, pp. 267-284.

33. Tam, R., Yassa, B., Parker, H., O’Connor, H., Allman-Farinelli, M. (2017): University students' on-campus food purchasing behaviors, preferences and opinions on food availability, Nutrition, no. 37, pp. 7-13. 


\title{
FAKTORI KOJI UTIČU NA IZBOR RESTORANA BRZE HRANE OD STRANE STUDENATA
}

\author{
Ivana Blešič́, Jovanka Popov Raljićc, Tatjana Pivac ${ }^{7}$, Milan Ivkov $^{8}$
}

\begin{abstract}
Sažetak
Globalno širenje navike konzumiranja brzih prehrambenih proizvoda $i$ posledična promena konkurentskog okruženja dovela je do veće pažnje usmerene na istraživanje tržišta i izdvajanje ciljnih grupa potrošača. Sa druge strane, rast tržišta i povećanje broja brzih restorana su ohrabrili potrošače da posvete veću pažnju proizvodima koje konzumiraju, odnosno uticali na njihov interes za raznolikost faktora koji su odlučujući prilikom izbora restorana.

Ovaj rad istražuje faktore koji utiču na izbor restorana brze hrane od strane studenata. Istraživanje je sprovedeno na Univerzitetu u Novom Sadu, a rezultati pokazuju da je najvažniji uticaj na izbor ovakve hrane pre svega blizina, pristupačnost, kao i higijenski faktori-čistoća restorana, kuhinje i uslužnog osoblja. Utvrđeno je postojanje razlike kod faktora izbora brze hrane prema polu ispitanika.
\end{abstract}

Ključne reči: fast food restorani, navike potrošača, studenti

5 Ivana Blešić, Dr, Vanredni profesor, Univerzitet u Novom Sadu, Prirodno-matematički fakultet, Departman za geografiju, turizam i hotelijerstvo, Trg Dositeja Obradoviča 3, 21000 Novi Sad, Srbija, Telefon: +381 214852835, E-mail: ivana.blesic@gmail.com

6 Jovanka Popov-Raljić, Dr, Redovni profesor, Univerzitet u Novom Sadu, Prirodnomatematički fakultet, Departman za geografiju, turizam i hotelijerstvo, Trg Dositeja Obradoviča 3, 21000 Novi Sad, Srbija, Telefon: +381 21 4852835, E-mail: jovankaraljicpopov@gmail.com

7 Tatjana Pivac, Dr, Vanredni profesor, Univerzitet u Novom Sadu, Prirodno-matematički fakultet, Departman za geografiju, turizam i hotelijerstvo, Trg Dositeja Obradoviča 3, 21000 Novi Sad, Srbija, Telefon: +38121 4852835, E-mail: tatjana.pivac@dgt.uns.ac.rs

8 Milan Ivkov, Dr, Docent, Univerzitet u Novom Sadu, Prirodno-matematički fakultet, Departman za geografiju, turizam i hotelijerstvo, Trg Dositeja Obradoviča 3, 21000 Novi Sad, Srbija, Telefon: +38121 4852842, E-mail: milan.ivkov@gmail.com 